\title{
PARALLEL BEAM NEUTRON COMPUTED TOMOGRAPHY RECONSTRUCTION WITH VARIOUS FILTERS
}

\section{PEMANFAATAN MATLAB UNTUK REKONSTRUKSI NEUTRON COMPUTED TOMOGRAPHY BERKAS PARALEL DENGAN BERBAGAI FILTER}

\author{
Mardiyanto', Bharoto1, Sutiarso', Maharini Ahsani Ummi² \\ ${ }^{1}$ Center for Technology of Nuclear Industry Materials, National Nuclear Energy Agency (BATAN) \\ 2 Department of Mathematic, Bandung Institute of Technology \\ e-mail: mardiyanto-panitra@yahoo.co.id
}

Received 15 June 2013, received in revised form 17 December 2013, accepted 03 February 2014

\begin{abstract}
PARALLEL BEAM NEUTRON COMPUTED TOMOGRAPHY RECONSTRUCTION WITH VARIOUS FILTERS. This paper presents a simple calculation using the MatLab application code for five different filter functions to obtain the best image quality for parallel beam neutron computed tomography. Shepp-Logan, Ramachandran-Lakshminarayanan, Cosine, Hamming and Hann Filter and without filter were used for a cross-section of a car coil ignitor reconstruction. The reconstruction was also done by varying the number of projections namely 180, 90, 45 and 12. The quality of the image can be determined by viewing the image directly or by using grey level curve to show the signal to noise image. The good images were determined by their signal-to-noise ratio (SNR) value. The high SNR values were obtained from the images which were reconstructed by using hamming and Hann filter. On the other hand the lowest SNR was obtained when the image was reconstructed without any filter. The number of the projections were also influenced the image quality, the more the projection number is used the better the image quality is obtained.
\end{abstract}

Keywords : Tomography, MatLab, filter, imaging/reconstruction

\section{ABSTRAK}

PEMANFAATAN MATLAB UNTUK REKONSTRUKSI NEUTRON COMPUTED TOMOGRAPHY BERKAS PARALEL DENGAN BERBAGAI FILTER. Telah dilakukan perhitungan sederhana menggunakan Matlab untuk lima fungsi filter yang berbeda untuk mendapatkan kualitas gambar terbaik dari neutron computed tomography berkas paralel. Shepp-Logan, Ramachandran-Lakshminarayanan, kosinus, Hamming dan Hann Filter dan tanpa filter yang digunakan dalam merekonstruksi tampang lintang dari koil pengapian mobil. Selain itu, rekonstruksi dilakukan dengan memvariasikan jumlah proyeksi yaitu 180, 90, 45 dan 12. Kualitas gambar dapat ditentukan dengan melihat gambar secara langsung atau dengan menggunakan kurva tingkat abu-abu untuk menunjukkan sinyal dan kebisingan gambar. Gambar-gambar yang baik diperoleh dari perbandingan sinyal / noise besar (SNR) yaitu gambar yang direkonstruksi dengan menggunakan Hamming dan Hann filter. Di sisi lain SNR terendah diperoleh ketika gambar direkonstruksi tanpa filter apapun. Jumlah proyeksi juga berpengaruh terhadap kualitas gambar, semakin banyak jumlah proyeksi semakin baik kualitas gambar.

Kata kunci: Tomografi, Matlab, Filter, pencitraan/rekonstruksi

\section{INTRODUCTION}

Industrial technology has developed very fast in parallel with the invention of a high speed computer. Various techniques have been developed for improving the quality of industrial products by adopting the high technology computer. The improvement has been carried out both in the qualities of the products as well as the efficiency of the production.

Nondestructive testing has become one of the techniques which has been used as the complement of a destructive testing for the product improvement and medical test such as Computed Tomography (CT) scanning. Recently, CT has been used not only for medical test purposes but also for the industrial technology (1-7).

CT is a method for imaging the cross-section of a sample by reconstructing the projection data. By using this technique the inner condition of the sample can be shown without any destruction. Various reconstruction 
algorithms have been made such as Fourier Convolution technique, ART, Fast Fourier Transform (FFT), and Simultaneous Iterative Reconstruction Technique. A comparison of the above methods has been carried out based on the image qualities with a given number of projections and given statistics by Z.H. Cho et al (8). A convolution method is widely used method for reconstructing data obtained by parallel modes of data collection. There are many reasons for this. The major reason is its computational simplicity and the required time for reconstruction is relatively short even using a Personal Computer.

Since the qualities of the reconstructed images strongly depend on the filter function, a comparison of various filter functions are carried out in this paper. The reconstruction technique is based on the Radon Transform which was proposed by G.T. Herman ${ }^{(9)}$. The theory of filter function has been presented in many books on image processing. It is predicted that the number of projection is one of the variables which determines the qualities of the reconstructed image. The larger the number of projections is used the better the quality of the image is obtained. X-ray Computed Tomography (XCT) has reached a mature technology and Neutron Computed Tomography (NCT) has become a complement of XCT (10-13). Briefly tomographic reconstruction process can be illustrated in the following block diagram (Figure 1) ${ }^{(14) .}$

$$
f(x, y) \rightarrow \text { Projection } \rightarrow p_{\varphi}(r) \rightarrow \text { Ramp filters } \rightarrow \bar{p}_{\varphi}(r) \rightarrow \text { Backprojection } \rightarrow f(x, y)
$$

Figure 1. Tomographic Reconstruction Block Diagram.

\section{METHODOLOGY}

The neutron television system (NTV) can be used to make a neutron tomography system by improving the hardware namely by addition of a turn table and data acquisition and tomography reconstruction software as shown in Figure 2. PTBIN-BATAN Neutron Tomography Facilities are shown in Figure 3.

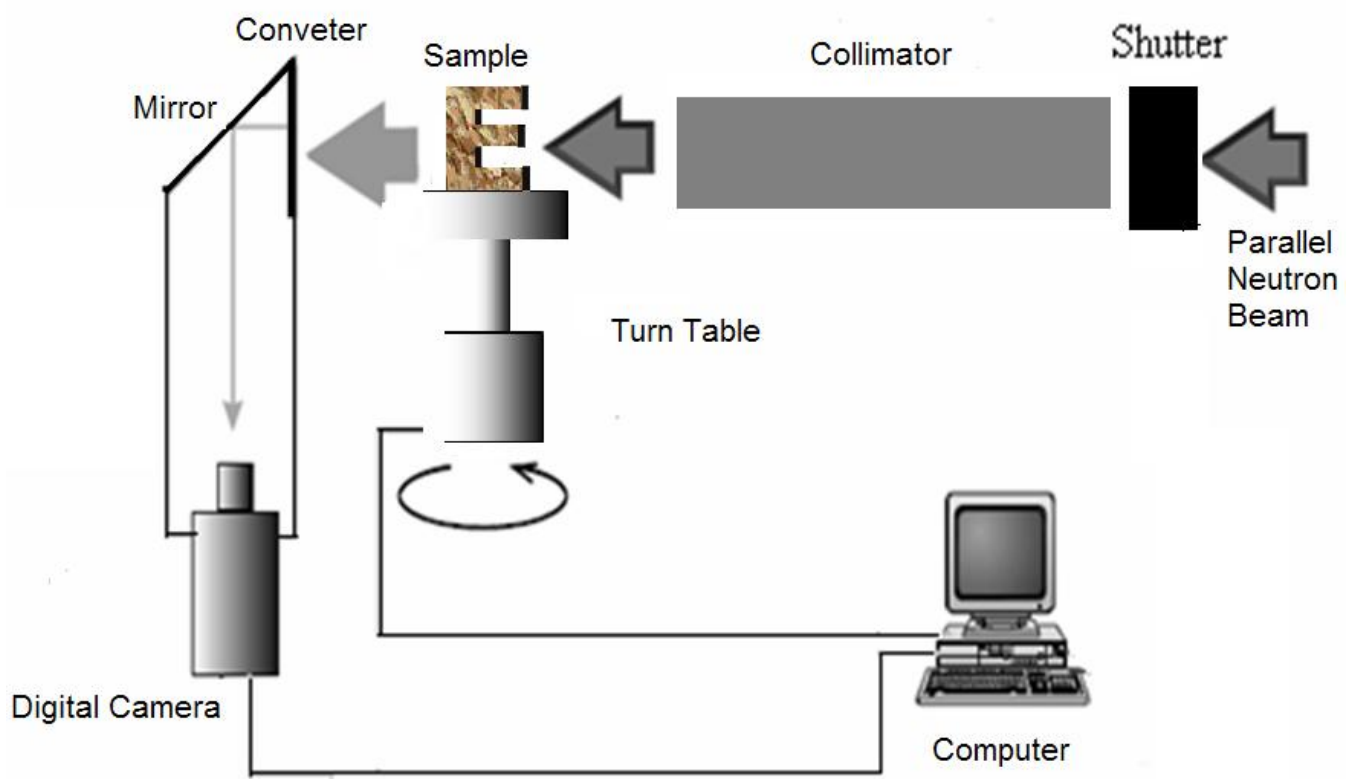

Figure 2. Neutron Computed Tomography Measurement System.

Projection data were measured and used as the input of the reconstruction software. The data were obtained from the projection images of a car ignitor coil (Figure 4). The sample was placed on the turn table and kept stable on it. The system was located in front of the outlet aperture of the neutron beam collimator. 


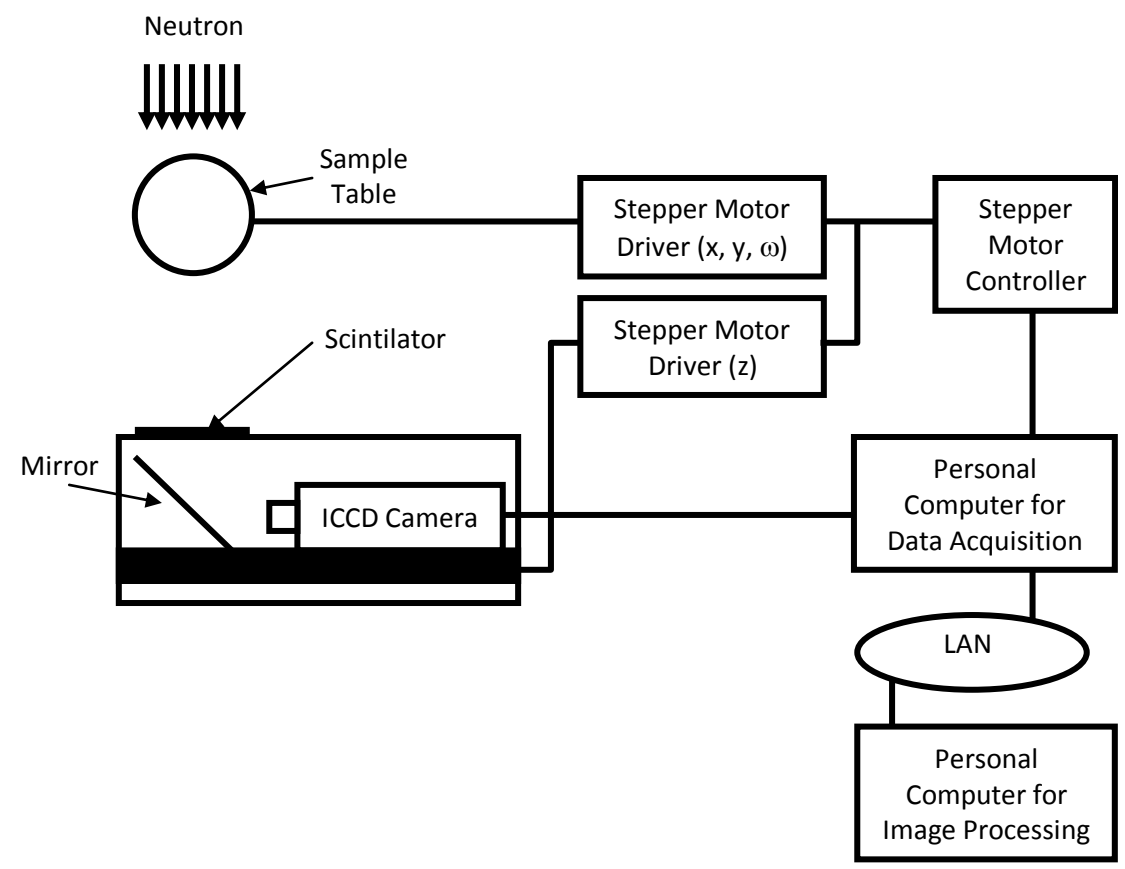

Figure 3. PTBIN-BATAN Neutron Tomography Facilities.

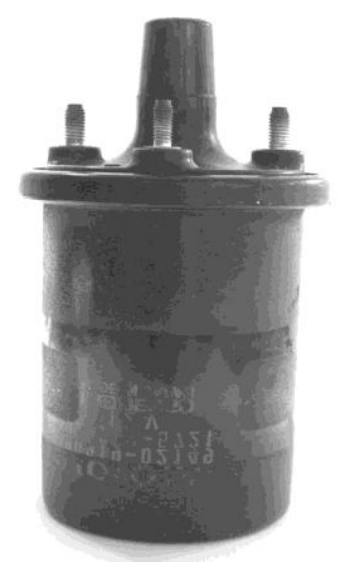

Figure 4. Toyota Kijang Car Ignitor Coil.

A parallel medium neutron beam passed through the object and the transmitted beam was measured by using the Andor's low light CCD camera (Figure1). The data were called as one projection data. In order to know the influence of the number of projection to the image qualities, 180 projections were made by turning the object $180^{\circ}$ with the step of 10 .

The next step was to make the reconstruction software. The tomography reconstruction software was made based on the convolution and back projection which is explained somewhere else ${ }^{(8,9)}$. Based on the theory, a reconstruction software was made by using MatLab 7.11 and the five filter functions were used shown in Table 1. The solution that has been implemented is based on the use of Matlab functions i.e. radon and iradon to complete the Filtered Back-projection process. Finally, by using the measured data which have been obtained the reconstruction was done. The reconstruction was done for the data with 1, 2, 4, 10 and 15 step degrees for each filter function. The flow chart of the reconstruction process is shown in Figure 5. 


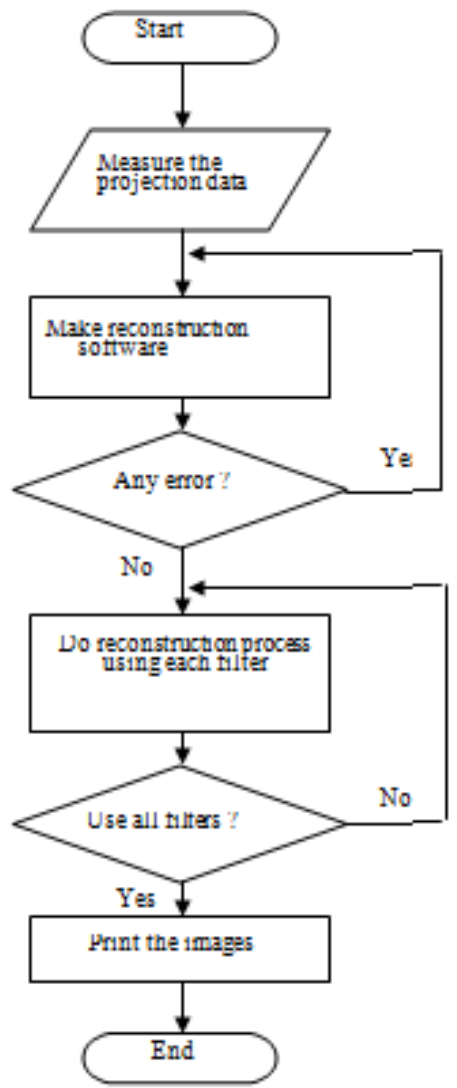

Figure 5. Flow chart of the tomography reconstruction process.

Table 1. Window Functions and a discrete filter function

\begin{tabular}{ll}
\hline Filter & Resp. Freq. $H(\xi)$ \\
\hline Ram-Lak & $H R L(\xi)|\xi| \operatorname{rect}(\xi d)$ \\
\hline Shepp-Logan & $|\xi| \operatorname{sinc}(\xi \mathrm{d}) \operatorname{rect}(\xi \mathrm{d})$ \\
\hline Cosine & $|\xi| \cos (\xi \mathrm{d}) \operatorname{rect}(\xi \mathrm{d})$ \\
\hline Hamming & $|\xi|[\alpha+(1-\alpha) \cos (2 \pi \xi \mathrm{d})] . \operatorname{rect}(\xi \mathrm{d})$ \\
\hline Hann & $0.5+0.5^{*} \cos (\pi \xi / \xi \mathrm{c})$ \\
\hline
\end{tabular}

\section{RESULTS AND DISCUSSION}

One of the projection images of the car ignitor coil is shown in Figure 6. The white lines shown in Figure 6 are the position of the cross section of the car ignitor coil which were reconstructed by using five filters as tabulated in Table 1 and without any filter. The results of the reconstructions are shown in Figure 16 for three different slice positions.

Figure 7 shows curves of grey level intensity of the projection image (Figure 6 ) at 5 different row positions i.e. $25,50,100,150$ and 250 . The five curves show that there are many spikes in each grey level intensity curve. The spikes may come from white spots which appear in the projection image shown in Figure 6. Black spots that appear in the image may be caused by the damage of the scintillator screen. While the white spots may be caused by the 
electronic noise. From the curves it can also be seen that the neutron intensity distribution in the imaging field is not homogeneous due to the imperfectness of the collimator design. The high neutron intensity is found within an area of $15 \mathrm{~cm}$ diameter in the center of the neutron beam and it is gradually decreasing radially

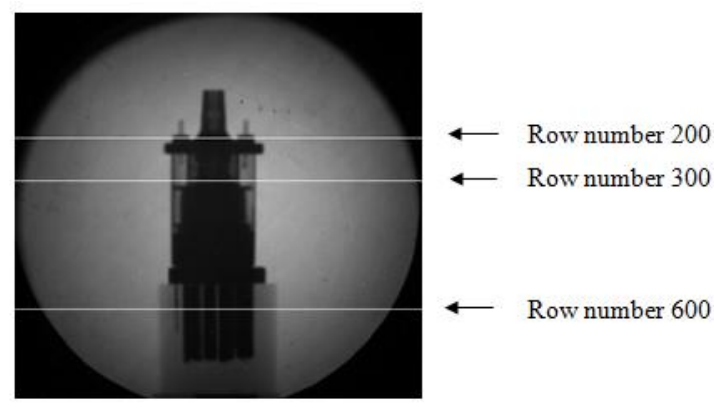

Figure 6. Projection Image of a car ignitor coil.

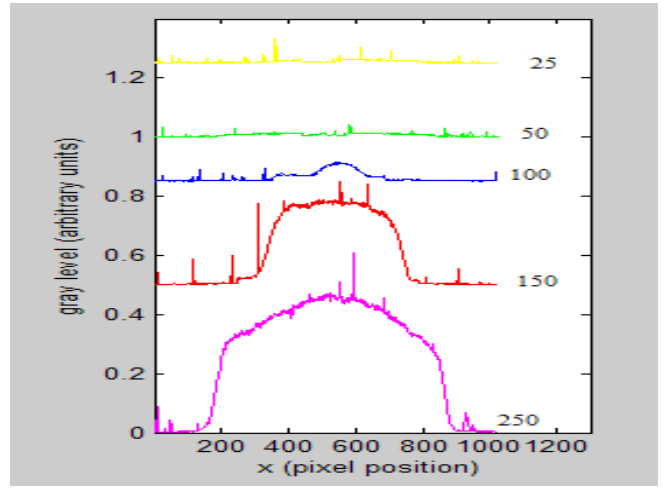

Figure 7. The intensity of slice Projection at the different row number.

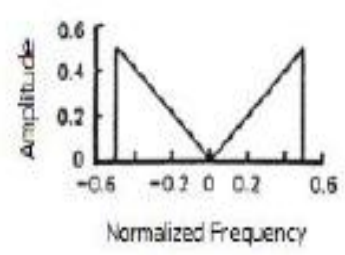

(a) Ramp filter

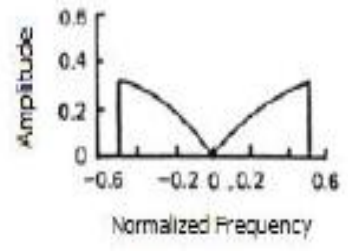

(b) Shepp-Logan filter

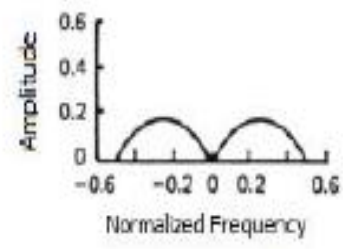

(c) Cosine filter

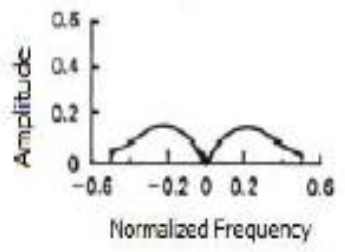

(d) Hamming-windowed filter

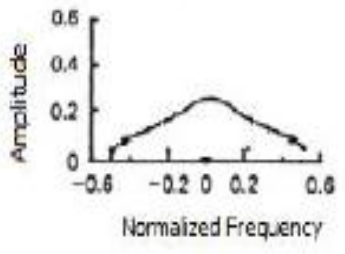

(e) Hanning-windowed filter

Figure 8. Five low pass filters used for CT reconstruction (15).

The most commonly used tomography reconstruction algorithm in commercial tomography is the filtered back projection algorithm. A filtered back projection is implemented in two stages. Firstly, filter the projection data using the so-called ramp filter. This process generates filtered projection data. Then, secondly, build up each pixel value by smearing the filtered projection data back across the image. The process of filtering in the first stage is usually implemented with standard Fourier filtering techniques. 


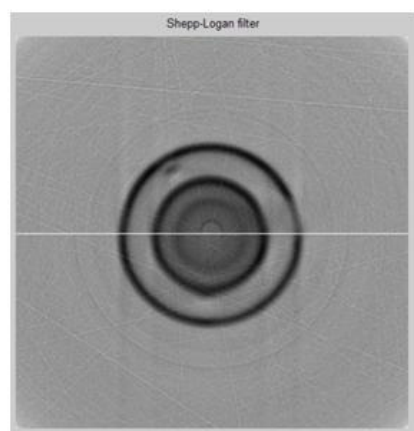

(a) Shepp Logan Filter

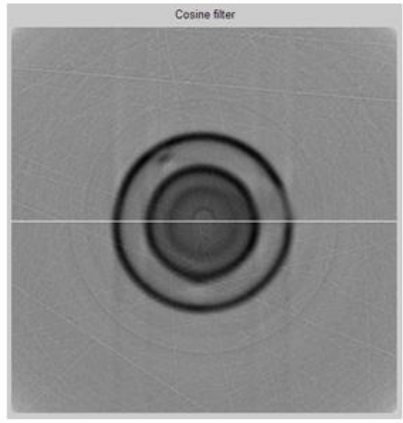

(c) Cosine Filter

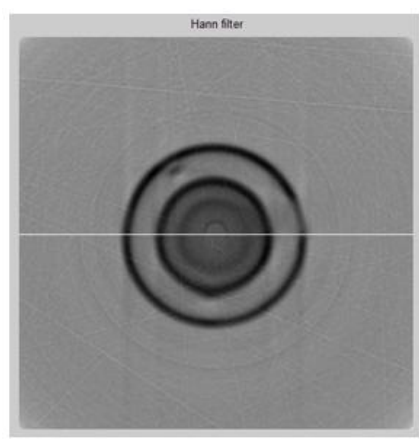

(e) Hann Filter

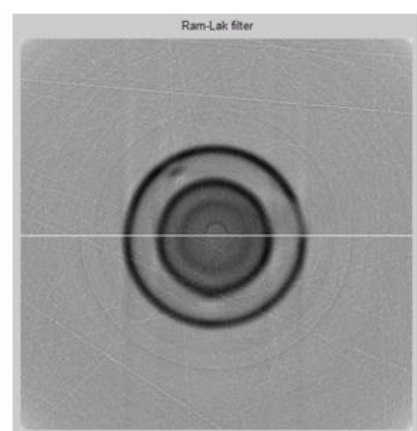

(b) Ram-Lak Filter

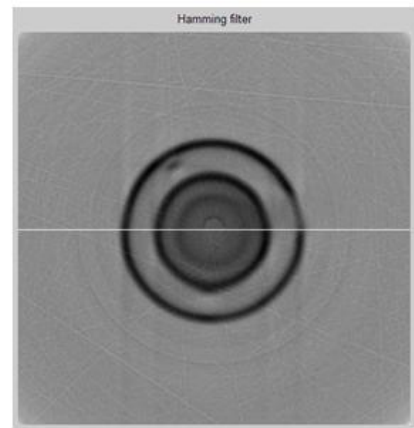

(d) Hamming Filter

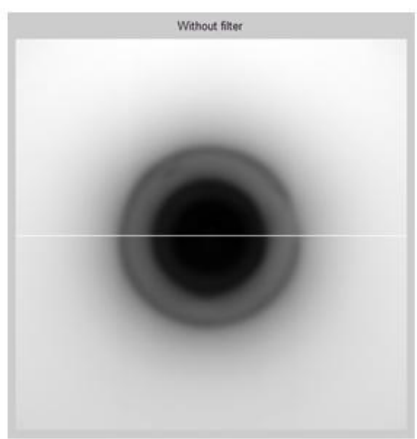

(f) Without any Filter

Figure 9. Tomography Image reconstruction of a car ignitor coil (line 500 and with 10 step).

A filter is used to get an original signal from a noisy signal that is obtained from a measurement. In computed tomography (CT), there are many types of noises such as star like artifact, ring artifact, and random noise. These noises spread over from low to high frequencies. The ideal ramp filter can not be practically implemented since the gain on this filter is infinite at an infinite frequency. However, $w_{\max }$ is the highest spatial frequency in the projection and therefore we can truncate the function at $w_{\max }$ resulting in the Ram-Lak filter. It can be seen in Figure 8.(a), Ram-Lak filter emphasizes higher frequencies, so that it often emphasizes noises in images. Therefore various modifications of this filter for noise reduction by suppressing the gain in high frequencies have been proposed. In this paper, to study the response of the modified filters, five smearing filters ( shown in Table 1) were used. Filter functions are actually low pass filters in the frequency domain (Figure 8). As it is well known that the main problem in the convolution-based reconstruction is the bargaining between the value of the bandwidth of the window and the sampling rate.From the mathematical point of view, it is desired that the bandwidth should be as big as possible in 
order not to lose the high frequency information, but on the other hand the sampling rate is restricted by the design of the machine. The best approximation is that the bandwidth is equal to $1 / d$, where $d$ is the spacing between two lines in one projection.

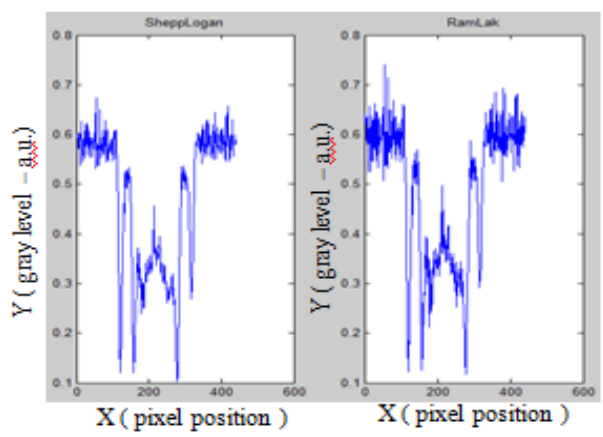

(a)

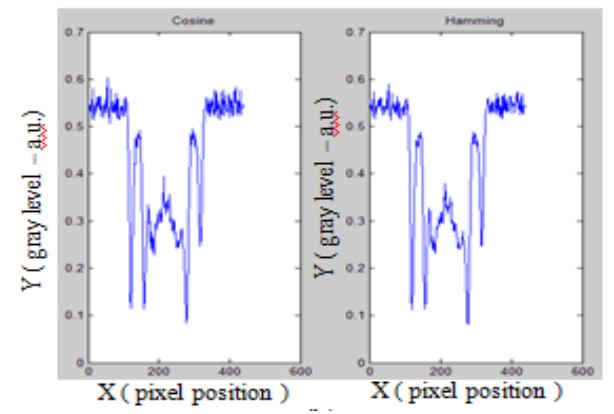

(b)

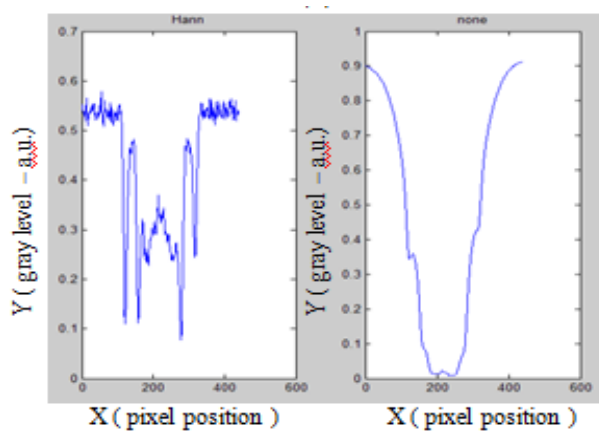

(c)

Figure 10. Grey level of horizontal pixel of the Tomography image shown by horizontal white line in Figure 9.

Figure 9 shows the results of the neutron tomography reconstruction of the car ignitor when the $500^{\text {th }}$ slice was reconstructed with 180 projections or $1^{10}$ sample rotation step. It can be seen from the images that by using five different filters, the reconstruction process produced almost similar images namely all the coil components at that slice appear clearly. Unfortunately, some ring artifacts are shown too. To reduce these artifacts it may be done by recalibrating the detector or using high resolution neutron screen conveter, so that the response of each radiation ray will be same. Figure 9.(f) shows the image of the car ignitor when it was recontructed without any filter and a blurred image was obtained. It may caused by hardware system resolution.

The quality of the tomography reconstruction can also be obtained by showing the grey level of one line taken from the reconstructed image. The grey level is depicted in Figure 10. The grey level curves show both the reconstructed signals and noises. The signals do not appear when no filter was used in the image reconstruction (Figure 10.(c)) 


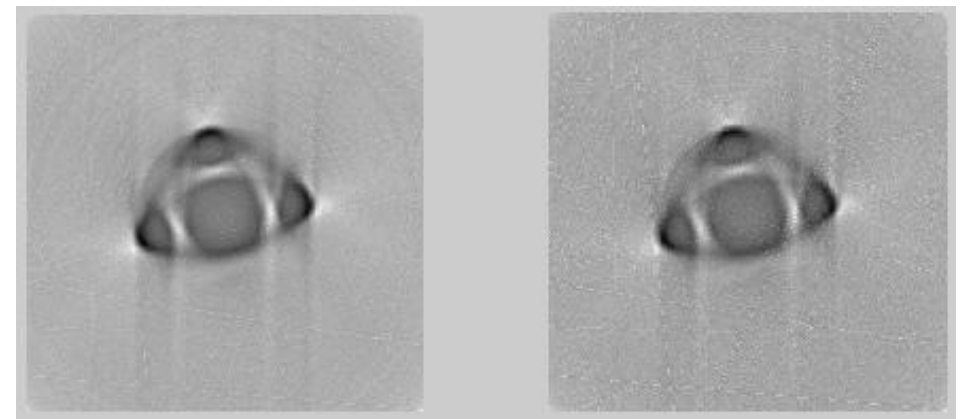
a. Shepp-Logan Filter
b. Ramachandran-Lakshminarayanan Filter

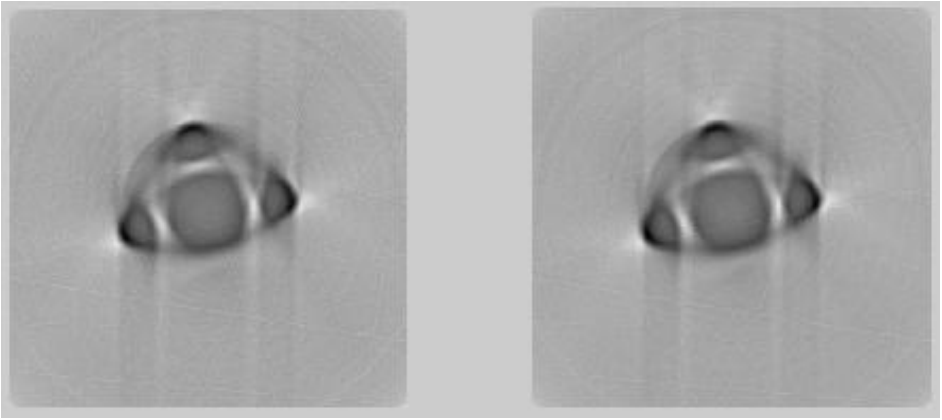

c. Cosine Filter

d. Hamming Filter

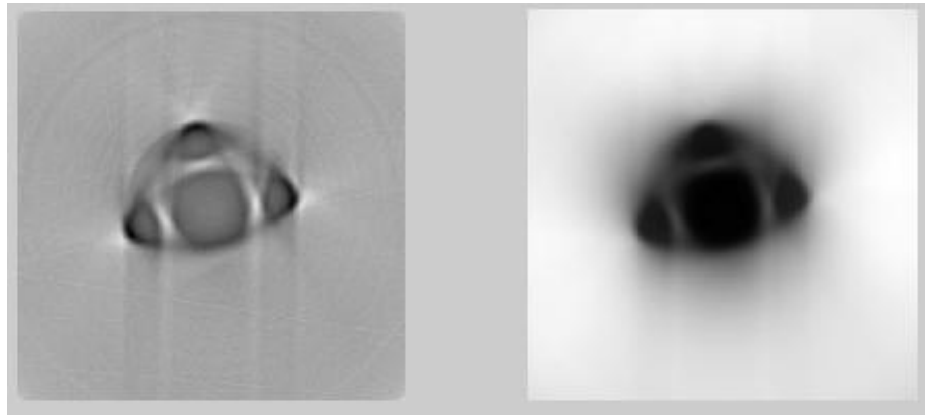

e. Hann Filter

f. Without Filter

Figure 11. Reconstruction with 10 step projection for slice 200.

However, both signal and noise are seen clearly with the different noise level when the five filters were used. By using these curves it can be determined their signal to noise ratio (SNR) qualitatively. The lowest noise level was obtained when Hann filter was used.

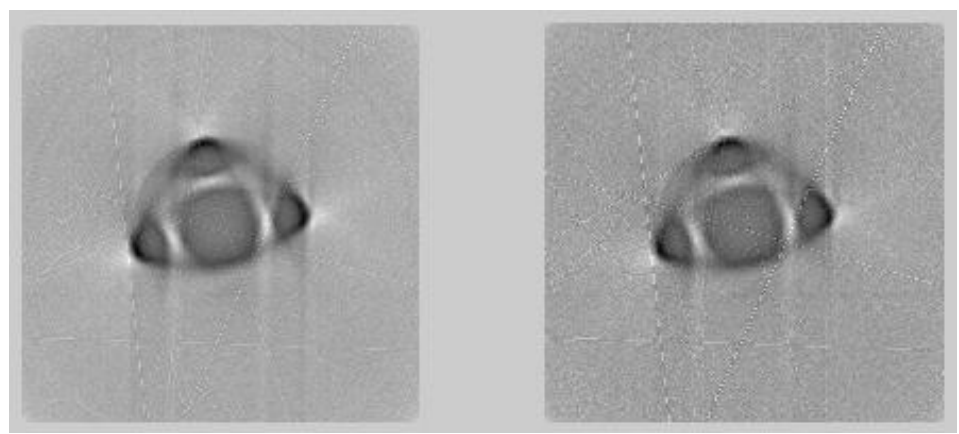
a. Shepp-Logan Filter
b. Ramachandran-Lakshminarayanan Filter 


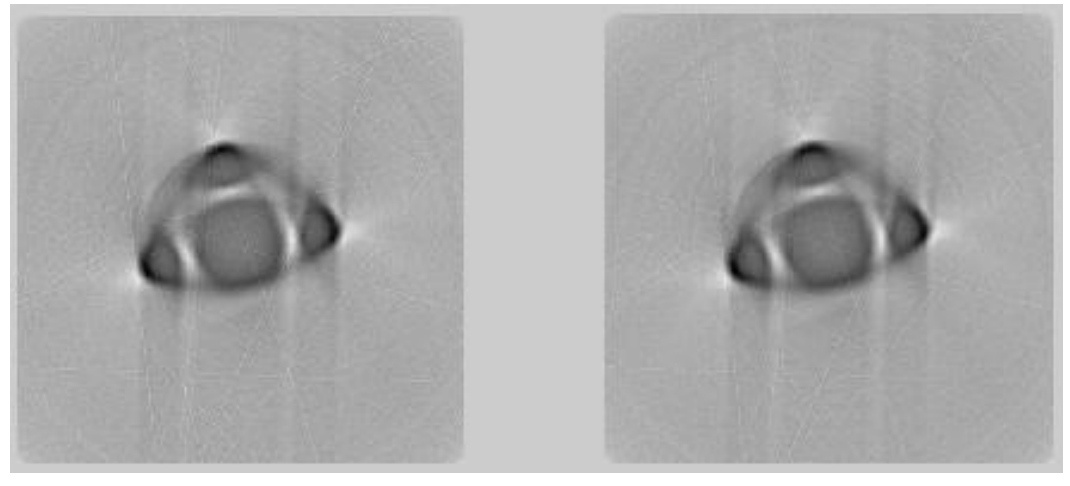

c. Cosine Filter

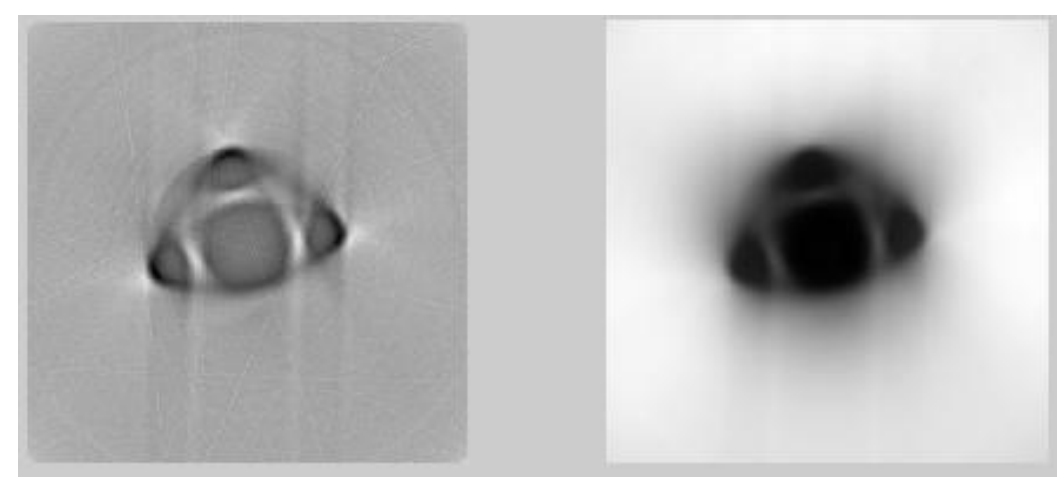

e. Hann Filter

f. Without Filter
Figure 12. Reconstruction with $2^{0}$ step projection for slice 200.

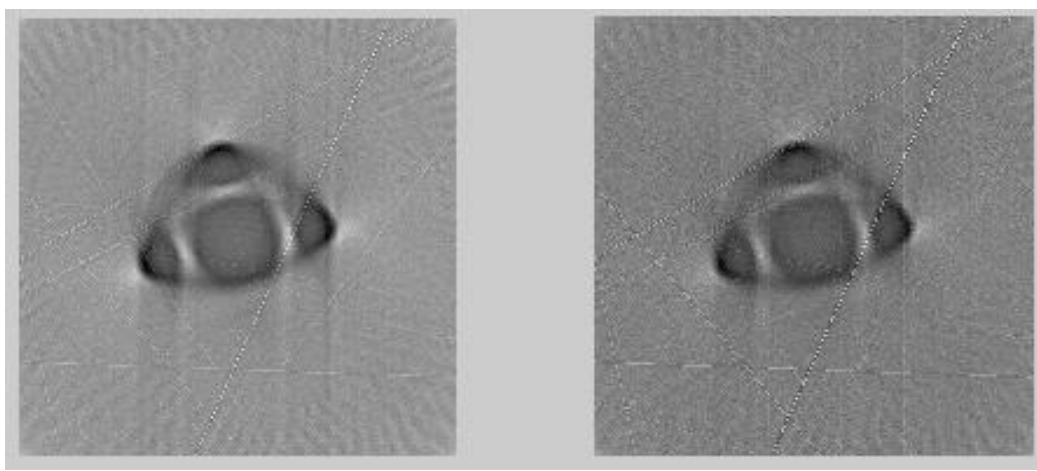

a. Shepp-Logan Filter

b. Ramachandran-Lakshminarayanan Filter

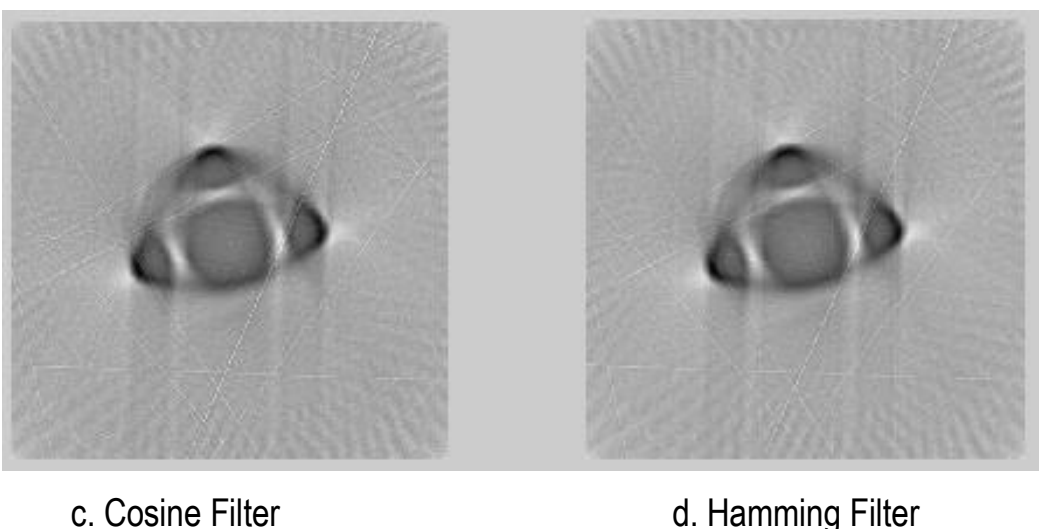




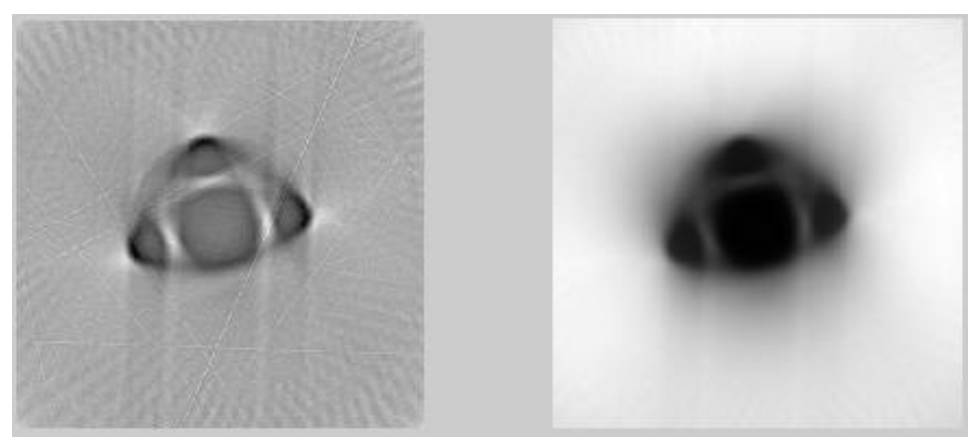

e. Hann Filter

f. Without Filter

Figure 13. Reconstruction with 40 step projection for slice 200.

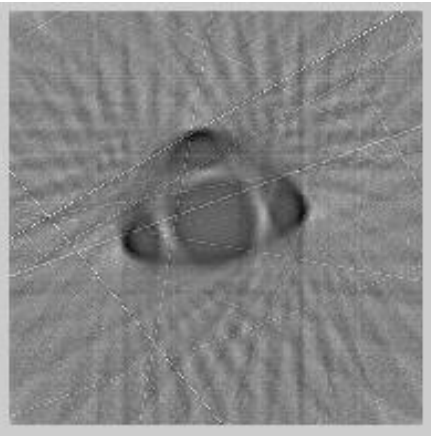

a. Shepp-Logan Filte

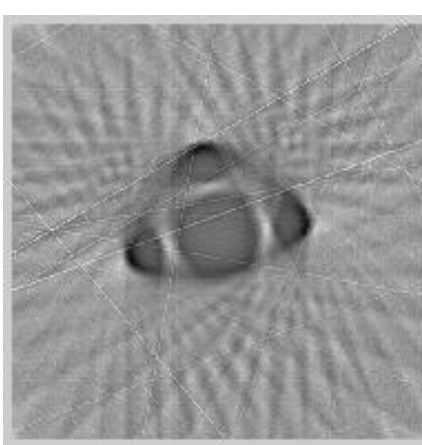

c. Cosine Filter

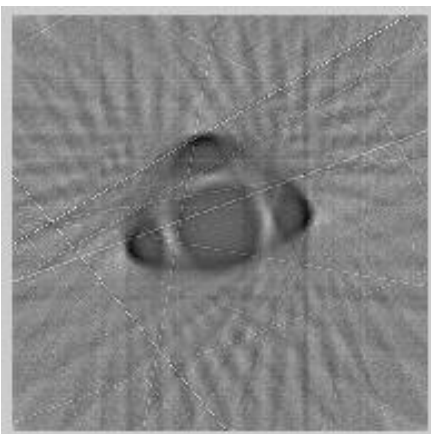

e. Hann Filter

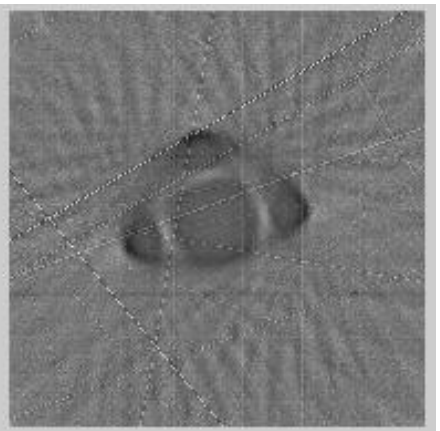

b. Ramachandran-Lakshminarayanan Filter

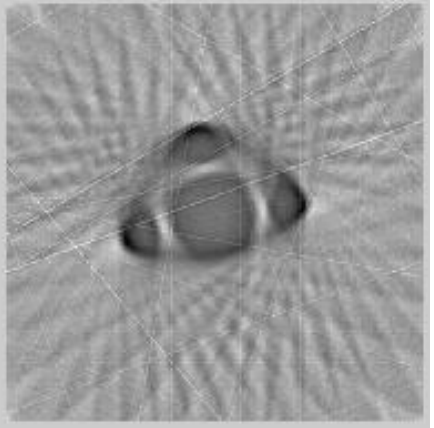

d. Hamming Filter

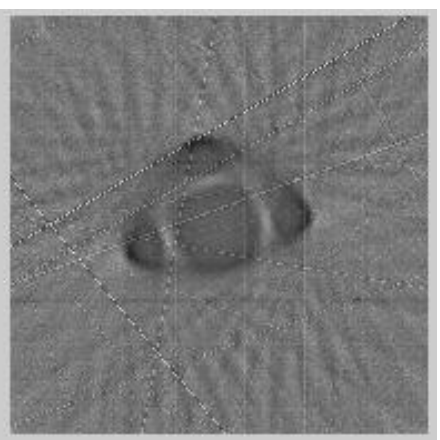

f. Without Filter

Figure 14. Reconstruction with $10^{0}$ step projection for slice 200. 


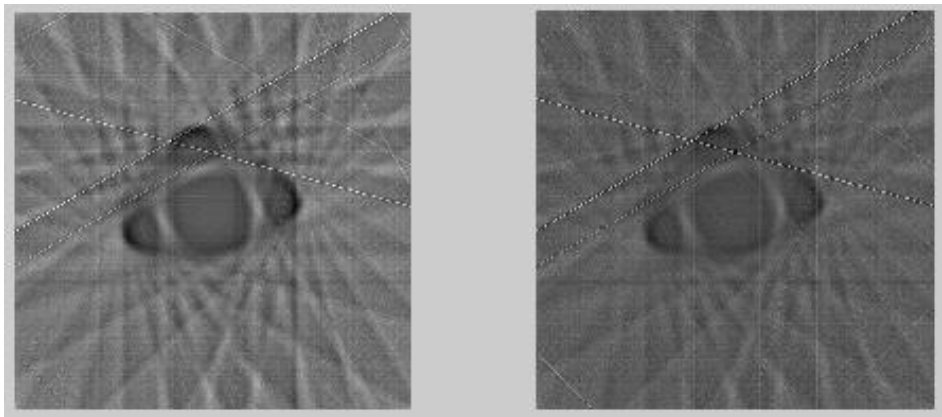

a. Shepp-Logan Filter

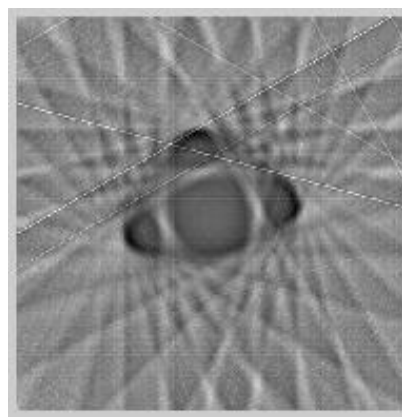

c. Cosine Filter

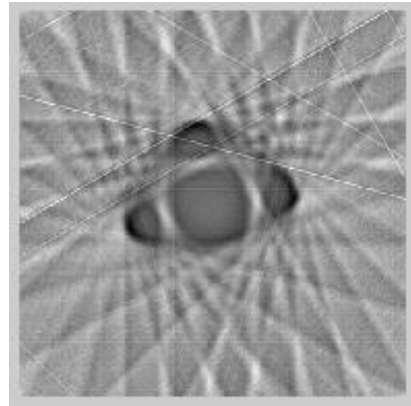

e. Hann Filter b. Ramachandran-Lakshminarayanan Filter

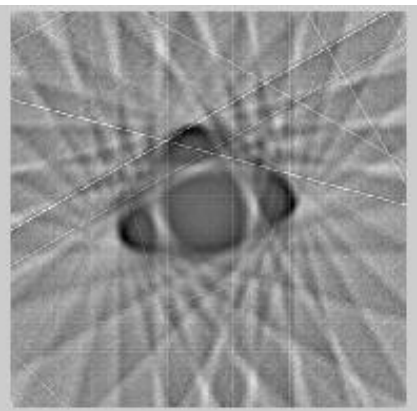

d. Hamming Filter

Figure 15. Reconstruction with $15^{0}$ step projection for slice 200.

Figure 11 to 15 show the image reconstruction results for 1, 2, 4, 10 and $15^{0}$ rotation step. From those figures it can be seen that the best image was obtained when the smallest rotation step was reconstructed namely as shown in Figure 10. In this facility the maximum projection is 360 projections or $0.5^{0}$ rotation step and it depends on the stepper motor being used. The star like artifact becomes more severely when the number of the rotation step is smaller.

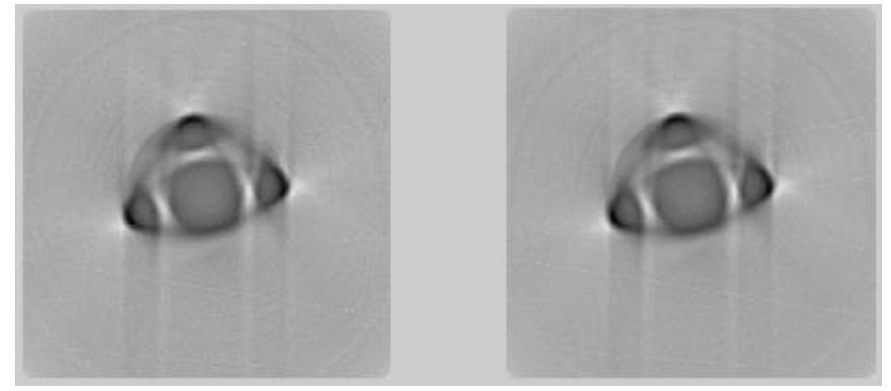

(a) 


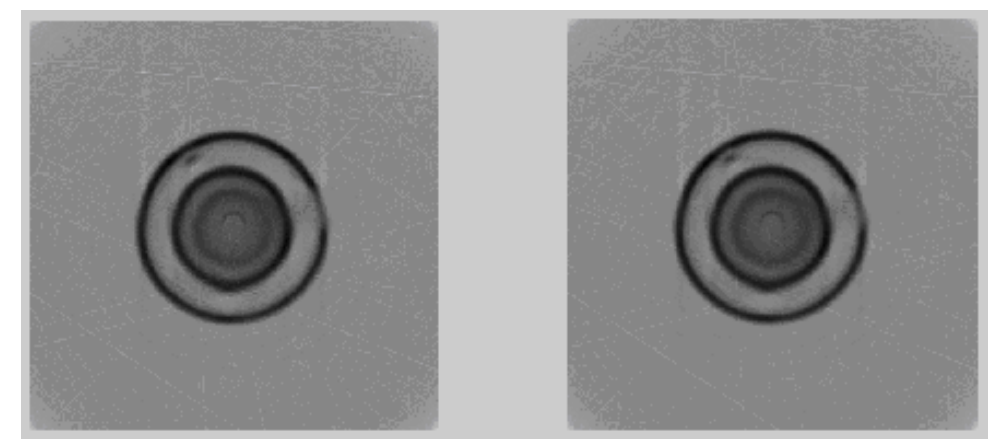

(b)

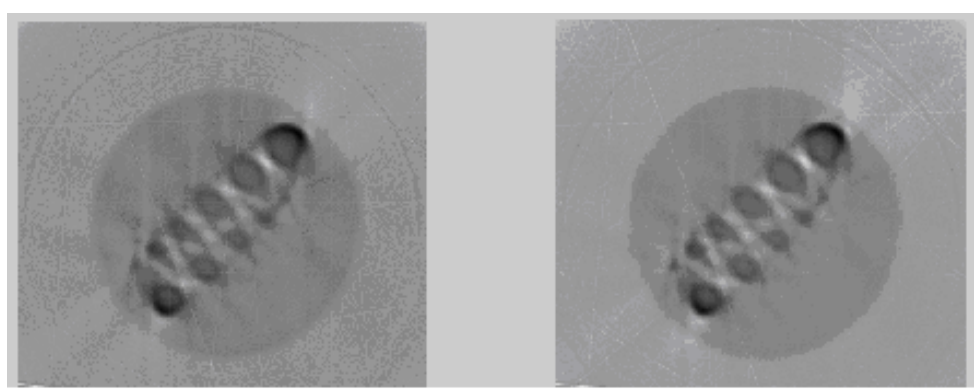

(c)

Figure 16. Reconstruction with $1^{0}$ step projection for slice 200, 300 and 600.

Figure 16 shows the results of the three different slice positions (200, 300 and 600) images with 180 reconstruction projections. In this paper only three different slices were reconstructed and shown. The reconstruction can be done for 1024 different slices or it is as high as the maximum resolution of the CCD camera.

\section{CONCLUSION}

By doing a very simple research, a comparative study of the utilization of various filter functions and five different projections was obtained. The calculation was done by using five different filter functions and by varying the projection number $(180,90,45$ and 12 projections) to obtain the best image qualities for parallel beam neutron computed tomography. Shepp-Logan, Ramachandran-Lakshminarayanan, Cosine, Hamming and Hann Filter were used in reconstructing a cross-section of a car ignitor coil. The quality of the image can be determined by viewing the image directly or by using grey level curve to show the signal and the noise of the image. The good images were obtained from the large signal/noise ratio (SNR) i.e. the images which were reconstructed by using hamming and Hann filter. On the other hand the lowest SNR was obtained when the image was reconstructed without any filter. Moreover, by increasing the projection number the better the image quality is obtained.

\section{REFERENCES}

1. IAEA-TECDOC-1589, Industrial Process Gamma Tomography Final report of a coordinated research project 2003-2007, http://www-pub.iaea.org/ MTCD/ publications/ PDF/te_1589_web.pdf, down loaded on January 15, (2013)

2. R. CHRISTOPH and H.J. NEUMANN, X-ray Tomography in Industrial Metrology, Precise, Economical and Universal, Printed in Germany 236020, ISBN 978-3-86236-020-8, (2011)

3. W.B. GILBOY, Medical and Industrial Tomography, Physical Methods, Instruments and Measurements, Vol-III. http://www.eolss.net/Sample-Chapters/C05/E6-08-03-04.pdf, down loaded on January 15, (2013) 
4. L. BUNGER, J.M. MACFARLANE, N.R. LAMBE, J. CONINGTON, K.A. McLEAN, K.MOORE, C.A. GLASBEY, G.SIMM, Use of X-Ray Computed Tomography (CT) in UK Sheep Production and Breeding, Sustainable Livestock Systems Group, Scottish Agricultural College, Edinburgh, UK (2011) 329-349

5. A.M. SHAIKH, Applications of various imaging techniques in neutron radiography at BARC, Trombay, 18th World Conference on Nondestructive Testing, Durban, South Africa (2012) 1208-1217

6. I. M. FIJAŁ-KIREJCZYK, J. J. MILCZAREK, M. J. RADEBE, F. C. DE BEER, J. ŻOŁADEK-NOWAK, Neutron Radiography Applications in Studies of Drying of Capillary-porous System, Drying Technology: An International Journal, Volume 31, Issue 8, Special Issue: Selected Papers from EuroDrying'2011 (2013) $872-880$

7. N. KARDJILOV, F. FIORI, G. GIUNTA, A. HILGER, F. RUSTICHELLI, M. STROBL, R. TRIOLO, and J. BANHART, Neutron tomography for archaeological investigations, Journal of Neutron Research 14(1), (2006) 29-36

8. Z.H. CHO and J.K. CHAN, A Comparative Study of 3-D Image Reconstruction Algorithms with Reference to Number of Projections and Noise Filtering, IEEE Trans. On Nuclear Science, Vol. NS-22 (1975) 344-358

9. G.T. HERMAN, Image Reconstruction from Projections, Academic Press, Inc. (London) LTD.(1980)

10. D. SCHWARZ, P. VONTOBEL, E. H. LEHMANN, C. A. MEYER, and G. BONGARTZ, Neutron Tomography of Internal Structures of Vertebrate Remains: A Comparison With X-Ray Computed Tomography, Palaeontologia Electronica, http://palaeo-electronica.org, down loaded on September 25, (2013)

11. A. KUBA, L. RODEK, Z. KISS, L. RUSKO, A. NAGY, M. BALASKO, Discrete tomography in neutron radiography, Nuclear Instruments and Methods in Physics Research A 542 (2005) 376-382

12. M. I. SILVANI, G. L. D. ALMEIDA, R. C. A. A. FURIERI, Thermal Neutron Computed Tomography at the Argonauta Reactor, Brazilian Journal of Physics, vol. 35, no. 3B (2005) 775-778

13. H. EGBERT, R. WALKER, R. FLOCCHINI, Neutron Tomography and Space, the University of California, Davis-McClellan Nuclear Radiation Center McClellan, California, USA 5335 Price Ave. McClellan, CA. 95652 916-614-6200 (2007)

14. J. FESSLER., Analytical Tomographic Image Reconstruction Methods, November 19, 2009. http://web.eecs. umich.edu/ fessler/course/516/// c-tomo.pdf, down loaded on January 28, (2013)

15. J. B. D. NOZAL, Use of Projection and Back-projection Methods in Bidimensional Computed Tomography Image Reconstruction, Master Thesis, Universitat Aotonoma de Barcelona (2009) 